Indonesian Journal of
$\begin{gathered}\text { Mathematics and Natural Sciences Education } \\ \text { p-ISSN:2721-172X AX e-ISSN: 2721-1746 } \\ \text { Vol. 1 No.2 Th 2020; hal 111-120 } \\ \text { http://mass.iain-jember.ac.id }\end{gathered}$

\title{
Representasi Matematis Siswa SMP Berkemampuan Tinggi dalam Menyelesaikan Soal Matematika
}

\author{
Fitri Ningrum Setiawati ${ }^{1}$, Soffil Widadah ${ }^{1,}{ }^{*}$, Eka Nurmala Sari Agustina ${ }^{1}$ \\ 1STKIP PGRI Sidoarjo. Sidoarjo, Indonesia \\ *E-mail: sofdah16@gmail.com
}

\begin{abstract}
Abstrak
Representasi matematis digunakan siswa ketika menghadapi soal matematika yang harus mereka selesaikan. Hal ini karena representasi matematis merupakan bentuk ungkapan ide yang ditampilkan siswa dalam bentuk yang beragam dalam situasi tertentu sebagai upaya menemukan solusi dari soal yang dihadapi. Rendahnya pemahaman siswa terhadap soal yang diberikan kemungkinan besar disebabkan oleh siswa yang tidak mampu menggunakan reprentasi matematis dengan benar. Penelitian ini merupakan penelitian deskriptif dengan pendekatan kualitatif yang bertujuan untuk mendeskripsikan representasi matematis siswa SMP, khususnya siswa berkemampuan tinggi dalam menyelesaikan soal matematika. Subjek penelitian ini merupakan salah satu siswa kelas VIII SMP 10 Nopember Sidoarjo yang dipilih berdasarkan tes kemampuan matematis. Hasil deskripsi data menunjukkan bahwa dalam menyelesaikan soal, siswa berkemampuan matematika tinggi cenderung menggunakan representasi visual untuk menyelesaikan masalah, membuat persamaan matematis atau ekspresi matematis, serta menjawab permasalahan dengan menggunakan kata-kata atau teks tertulis dengan hasil penyelesaian soal sebagian besar benar.
\end{abstract}

Kata Kunci: Menyelesaikan Soal, Representasi Matematis.

\section{PENDAHULUAN}

National Council of Teachers of Mathematics (NCTM, 2000) telah menetapkan bahwa terdapat lima keterampilan proses yang perlu dimiliki siswa melalui pembelajaran matematika. Keterampilan tersebut tercakup dalam standar proses, yaitu penyelesaian masalah (problem solving), penalaran dan pembuktian (reasoning and proof), komunikasi (communication), koneksi (connection), dan representasi (representation). Berdasarkan uraian tersebut, terlihat bahwa kemampuan menyelesaikan soal dan representasi merupakan bagian dari kurikulum matematika yang penting dalam proses pembelajaran matematika.

Representasi erat kaitannya dengan penyelesaian masalah, seperti yang diungkapkan Salkind dan Hjalmarson (Susanah, 2016),

"Students use representations to support understanding when they are solving mathematical problems or learning new mathematical concepts".

Pernyataan tersebut bermakna bahwa "Siswa menggunakan representasi untuk mendukung pemahaman 
ketika mereka menyelesaikan masalah atau mempelajari konsep-konsep matematika yang baru ditemui siswa". Dengan kata lain, siswa membutuhkan representasi untuk menyelesaikan masalah (soal). Representasi adalah bentuk ungkapan pemikiran siswa (baik itu berupa kata-kata atau verbal; tulisan; gambar; tabel; grafik; benda konkrit; ataupun simbol matematika) yang dapat digunakan sebagai alat bantu untuk memahami dan menemukan solusi dari suatu situasi masalah yang sedang dihadapi. Ketepatan represen-tasi yang digunakan juga berperan dalam menentukan ketepatan solusi dari masalah (soal) yang dihadapi.

Istadi, dkk (2017), representasi siswa memungkinkan siswa untuk memilih, menerapkan, dan menerjemahkan representasi matematis untuk menyelesaikan masalah. Misalnya, menterjemahkan antara masalah matematika dan representasi matematis serta menerjemahkan representasi matematika itu sendiri. Dengan demikian, siswa harus dapat berpikir secara fleksibel dalam berbagai bentuk representasi. Hal ini mengisyaratkan bahwa siswa harus menggunakan representasi mate-matis untuk memecahkan masalah, karena menggunakan representasi lebih efisien membantu memfasilitasi siswa ketika memecahkan masalah. Misalnya, representasi visual dapat memfasilitasi dalam memecahkan masalah aljabar daripada menggunakan representasi simbolik, meskipun sebelumnya siswa lebih cenderung menyukai representasi visual.

Terkait kemampuan penyelesaian masalah untuk siswa di sekolah, Widadah (2015) menyatakan bahwa siswa harus mampu menyelesaikan masalah baik ditinjau dari kesiapan mental maupun pengetahuan, terlepas dari apakah pada akhirnya sampai atau tidak pada jawaban masalah tersebut. Berdasarkan pendapat tersebut, kemampuan penyelesaian masalah harus dimiliki oleh siswa agar siswa mampu menghadapi atau menyelesaikan masalah matematika yang nantinya dapat digunakan dalam kehidupan seharihari. Dengan demikian siswa akan mampu bersaing ditengah perkembangan zaman, khususnya dalam perkembangan teknologi modern. Hal ini tentu menjadi kebutuhan setiap siswa. Dengan demikian, kemampuan penyelesaian merupakan kemampuan yang menjadi fokus dalam proses pembelajaran yang perlu untuk ditingkatkan.

Ketika siswa dihadapkan pada suatu soal matematika, siswa akan berusaha untuk menyelesaikannya dengan menggunakan cara-cara yang diketahui atau dipahami. Salah satu bagian dari upaya siswa adalah dengan membuat representasi matematis dari masalah tersebut. Representasi yang dibuat siswa bisa beragam bergantung pada kemampuan setiap individu yang beragam pula, yaitu ada yang berkemampuan tinggi, sedang, atau rendah. Rusminati (2014) menyatakan bahwa bentuk representasi yang dimunculkan siswa dalam memecahkan masalah dipengaruhi oleh tingkat kemampuan matematikanya.

Berdasarkan pendapat beberapa ahli dan pentingnya kemampuan representasi bagi siswa dalam menyelesaikan soal, maka penelitian ini bertujuan untuk mendeskripsikan kemampuan rep- 
resentasi matematis siswa yang dilihat berdasarkan tingkat kemampuan matematika siswa. Dalam penelitian ini lebih berfokus pada siswa berkemampuan tinggi, agar lebih mengetahui bentuk representasi yang dimunculkan oleh siswa berkemampuan tinggi dalam menyelesaikan soal. Siswa berkemam-puan tinggi diharapkan mampu menyelesaikan soal menggunakan kemampuan representasinya dengan baik. Dengan demikian, perlu dilakukan penelitian ini untuk melihat kemampuan representasi matematis siswa berkemampuan matematis tinggi.

Penelitian ini berfokus pada materi himpunan, sehingga terdapat batasanbatasan mengenai bentuk representasi yang akan dideskripsikan dengan mengadaptasi indikator representasi matematis yang dijelaskan oleh Catharina (2016). Untuk kelompok representasi visual, fokus representasi yang diharapkan adalah representasi gambar atau diagram karena repre-sentasi yang sesuai dengan materi diagram venn adalah representasi gambaratau diagram. Pada kelompok representasi simbolik (persamaan mate-matis atau ekspresi matematis), peneliti memfokuskan pada bentuk ekspresi matematis seperti penggunaan operasi hitung dasar penjumlahan, pengurang-an, pembagian dan perkalian. Sedang-kan dalam kelompok representasi verbal (katakata atau teks tertulis), peneliti memfokuskan pada represen-tasi berupa kata-kata yang dijelaskan secara lisan dan didukung oleh teks tertulis dalam menyelesaiakan soal. Untuk lebih jelasnya dapat dilihat pada tabel 1 indikator representasi matematis berikut ini.
Tabel 1. Indikator Representasi Matematis

\begin{tabular}{|c|c|c|}
\hline No. & Representasi & $\begin{array}{c}\text { Bentuk-bentuk } \\
\text { Operasional }\end{array}$ \\
\hline$(1)$ & (2) & (3) \\
\hline 1. & $\begin{array}{l}\text { Representasi } \\
\text { Visual }\end{array}$ & $\begin{array}{l}\text { Menyajikan } \\
\text { kembali data } \\
\text { atau informasi ke } \\
\text { bentuk gambar } \\
\text { atau diagram. }\end{array}$ \\
\hline 2. & $\begin{array}{l}\text { Persamaan } \\
\text { matematis atau } \\
\text { ekspresi } \\
\text { matematis }\end{array}$ & $\begin{array}{l}\text { Menyelesaikan } \\
\text { masalah dengan } \\
\text { melibatkan } \\
\text { ekspresi } \\
\text { matematis. }\end{array}$ \\
\hline 3. & $\begin{array}{l}\text { Kata-kata atau } \\
\text { teks tertulis }\end{array}$ & $\begin{array}{l}\text { Menjawab soal } \\
\text { dengan } \\
\text { menggunakan } \\
\text { kata-kata atau } \\
\text { teks tertulis. }\end{array}$ \\
\hline
\end{tabular}

\section{METODE}

Penelitian ini merupakan penelitian deskriptif dengan pendekatan kualitatif. Penelitian ini dilakukan di SMP 10 Nopember Sidoarjo. Tes Kemampuan Matematika (TKM) digunakan sebagai penentu tingkat kemampuan matematika siswa dan nantinya akan dipilih 1 orang siswa berkemampuan tinggi yang mampu berkomunikasi dengan baik. Kriteria siswa berkemampuan tinggi dalam penelitian ini menggunakan kriteria yang ditetapkan oleh Ratumanan dan Laurens (2011), yaitu siswa mempunyai skor antara 80 dan $100(80 \leq$ skor $\leq 100)$.

Selanjutnya subjek terpilih harus mengerjakan Tes Representasi Matematika (TRM) dan wawancara terkait TRM. Soal TRM terdiri dari dua soal: soal pertama cenderung untuk mengungkap indikator 1 dan 3, yaitu representasi visual dan representasi berupa kata- 
kata atau teks tertulis; sedangkan soal kedua cenderung untuk mengungkap indikator 2 dan 3, yaitu representasi dalam bentuk ekspresi matematis dan representasi berupa kata-kata atau teks tertulis. Triangulasi teknik digunakan untuk menguji kredabilitas data dalam penelitian ini dilakukan dengan cara mengecek data kepada subjek yang sama dengan teknik yang berbeda. Analisis data akan dilakukan setelah subjek penelitian menyelesaikan TRM dan diwawancara, selanjutnya dideskripsikan. Data tersebut akan dianalisis berdasarkan indikator dari representasi matematis siswa.

\section{HASIL DAN PEMBAHASAN}

Berdasarkan hasil TKM, diperoleh nama-nama subjek berdasarkan kriterianya yaitu dua subjek berkemampuan matematika tinggi yaitu MRWdan VRI. Pada kesempatan kali ini, peneliti memaparkan representasi matematis subjek MRW. Adapun pembahasan hasil deskripsi representasi matematis siswa sebagai berikut.

\section{Representasi Visual}

Siswa dikatakan melakukan representasi visual apabila menyajikan kembali data atau informasi dari suatu ben-
Gambar 1 menunjukkan hasil jawaban MRW pada soal TRM nomor 1,yaitu siswa mampu menyajikan kembali data atau informasi yang diperoleh dari soal dengan cara mengubah soal ke bentuk diagram venn. Bentuk diagram venn yang dibuat oleh MRW sudah mendekati benar namun masih ada bagian diagram yang kurang lengkap, yaitu bagian diagram yang berbentuk dua lingkaran beririsan hanya diberi nama $a$ dan $b$ tanpa memberi keterangan tentang objek yang diwakili oleh $a$ dan $b$.

Penggunaan diagram venn yang dilakukan oleh MRW juga diperkuat dengan hasil wawancaraantarapeneliti (P) dengan MRW (S) berikut.

$\mathrm{P}$ : “Sekarang coba kamu perhatikan soal tersebut!"

S : (sambil mengangguk) "Iya kak"

$\mathrm{P}$ : "Apa saja yang diketahui dari soal tersebut?"

S : "Berdasarkan soal itu diketahui jumlah seluruh siswa dalam kelas sebanyak 40 siswa. 6 siswa menyukai keduanya, 4 siswa tidak menyukai keduanya, dan banyak siswa yang menyukai Karate $2 \times$ Taekwondo."

P : “Apa yang ditanyakan dari soal tersebut?"

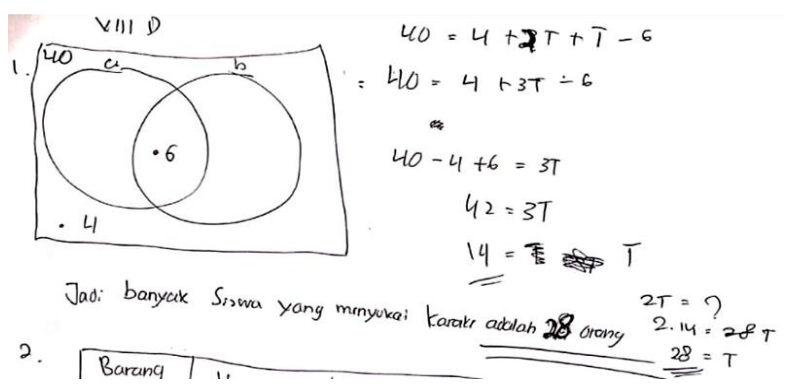

Gambar 1. Hasil Jawaban MRW pada Soal TRM 1

tuk ke bentuk gambar. Berikut hasil jawaban siswa dari soal TRM nomor 1 .
S : "Yang ditanyakan banyak siswa yang menyukai Karate."

P : “Langkah apa yang pertama kali 
kamu ambil untuk menyelesaikan soal tersebut?"

S : "Membuat diagram Venn dan memasukan angka-angka yang diketahui kedalam diagram untuk mempermudah memahami soal kak"

Berdasarkan hasil wawancara, MRW memilih menggunakan diagram venn untuk membatunya menyelesaikan soal TRM nomor 1 . Dengan demikian, jika dianalisis dari hasil tes tertulis dan wawancara, MRW dapat menyajikan informasi dari soal kedalam bentuk gambar atau diagram, sehingga dapat dikatakan MRW telah memenuhi indikator 1 kemampuan representasi matematis yaitu mampu menggunakan representasi visual.

\section{Ekspresi Matematis}

Siswa dikatakan melakukan representasi berupa ekspresi matematis apabila siswa menggunakan ekspresi matematis dalam menyelesaikan masa-lah. Berikut merupakan hasil pekerjaan siswa pada soal TRM nomor 2 . belian kedua barang, serta membandingkan harga beli dimasing-masing toko. Namun MRW kurang teliti dalam melakukan operasi hitung. Hal ini terlihat pada bagian gambar 2 yang digaris bawahi warna merah. Akibatnya terdapat kesalahan hasil penghitungan yang berakibat pada proses penghitungan berikutnya.

Penggunaan ekspresi matematis untuk merepresentasikan soal TRM nomor 2 juga dijelaskan MRW melalui hasil wawancara berikut.

P : "Bagaimana kamu menyelesaikan soal ini ?"

$S$ : "Jadi untuk mengetahui masingmasing harga di setiap toko setelah mendapatkan diskon yaitu dengan cara mencari harga baju dan celana setelah di diskon. Kemudian saya bandingkan masing-masing harga disetiap toko. Berdasarkan penyelesaian saya Ali akan berbelanja di toko Rame untuk memperoleh harga yang paling murah."

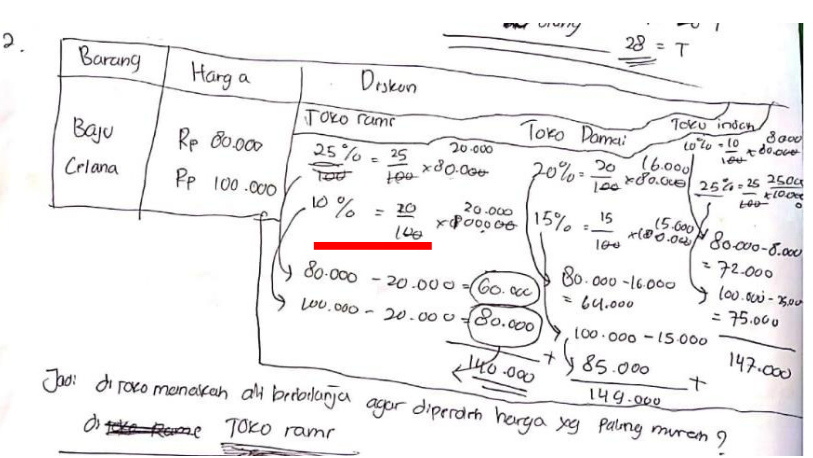

Gambar 2. Hasil Jawaban Tertulis MRW pada Soal TRM Nomor 2

Gambar 2 menunjukkan bahwa siswa mampu menyelesaikan masalah dengan melibatkan ekspresi matematis. Penjelasan sebagian besar benar. Siswa menjelaskan menggunakan ekspresi matematis secara runtut mulai dari mencari harga setelah barang mendapat diskon, menjumlahkan hasil dari pem-
P : “Jelaskan bagaimana kamu membuat persamaan dari soal ini ?"

S : "Saya ambil contoh toko Rame ya kak ? misal toko rame kan untuk diskon baju 25\% sedangkan diskon celana $10 \%$. Saya membuat tabel seperti soal kemudian mensubtitusikan setiap diskon saya ambil diskon baju 25\% maka persamaan matematikannya 
$\frac{25}{100} \times$ Rp. $80.000=$ Rp. 20.000

Maka harga setelah diskon adalah

Rp. 80.000 - Rp. 20.000 = Rp. $60.000 . "$

Dari hasil wawancara MRW mampu menggunakan ekspresi matematis terkait mencari diskon dan harga barang setelah diskon.

Selainitu, terdapat kemampuan MRW untuk menggunakan representasi berupa ekspresi matematis juga terlihat pada hasil tes dan wawancara pada soal TRM nomor 1. Berikut hasil pekerjaan MRW pada soal TRM nomor 1 yang berkaitan dengan penggunaan ekspresi matematis.

Berdasarkan gambar 3, MRW telah dapat membuat model matematika dari matematis karena mampu menyajikan model matematika dari soal yang diberikan dengan benar.

Hal ini didukung juga dengan hasil wawancara peneliti dengan MWR sebagai berikut.

P : "Bagaimana proses penyelesaiannya ?"

S : "Pertama mancari banyak siswa yang menyukai taekwondo dengan cara mengubah soal kedalam model matematika yaitu

$$
\begin{aligned}
40 & =4+3 \mathrm{~T}-6 \\
40-4+6 & =3 \mathrm{~T} \\
42 & =3 \mathrm{~T} \\
\mathrm{~T} & =14
\end{aligned}
$$

Karena disoal diketahui siawa yang menyukai Karate tadi 2x Taekwondo

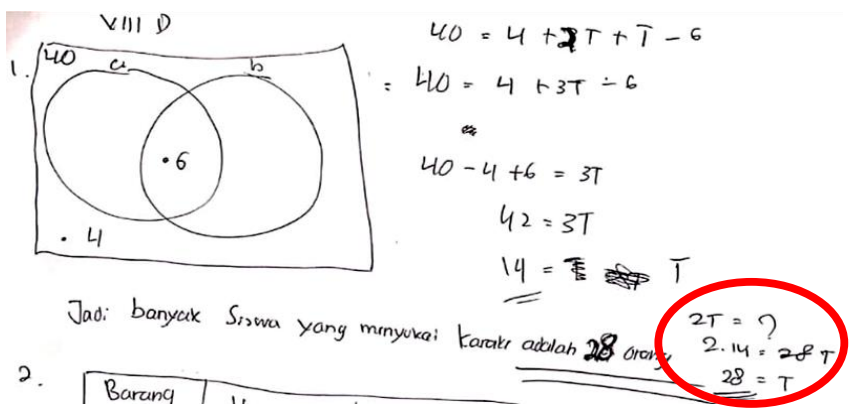

Gambar 3. Hasil Jawaban MRW pada Soal TRM Nomor 1 yang Berkaitan dengan Ekspresi Matematis

soal TRP nomor 1 dengan tepat dan melakukan penghitungan dengan tepat dari model matematika yang dibuat. Namun terdapat sedikit kekeliruan yang ditulis oleh MRW yang ditunjukkan oleh bagian liangkaran merah. MRW menuliskan "2.14 = $28 \mathrm{~T}$ " dan "28 $=\mathrm{T}^{\prime}$ padahal sebelumnya MRW menuliskan "2T?" yang sebenarnya telah dijawab MRW dengan penulisan "2.14". Akan tetapi MRW mampu menjawab pertanyaan dengan benar yang terlihat dari tulisan MRW pada bagian kesimpulan. Dengan kata lain, MRW tetap dapat dikatakan mampu menggunakan representasi matematis berupa ekspresi maka banyak siswa yang menyukai karate adalah $2 \times 14=28$."

Berdasarkan ha sil wawancara, terlihat MRW dapat menuliskan model matematika sebagai ekspresi matematis dari apa yang diketahui dalam soal dengan benar.

Dengan demikian, jika dianalisis dari hasil tes tertulis dan wawancara peneliti dengan siswa pada tes representasi matematis soal nomor 1 dan nomor 2, maka dapat dikatakan bahwa siswa dapat menyelesaikan masalah dengan melibatkan ekspresi matematis. Hal ini menunjukkan bahwa MRW 
memenuhi indikator representasi matematis nomor 2 yaitu menggunakan persamaan matematis atau ekspresi matematis dalam menyelesaikan soal.

\section{Kata-kata atau Teks Tertulis}

Kemampuan siswa terkait menggunakan representasi matematis berupa kata-kata atau teks tertulis dapat dilihat dari jawaban siswa pada soal TRM nomor 1 dan 2 yang dianalisis dari hasil wawancara peneliti dengan MRW.Pada tahap persiapan ini menggunakan data kebutuhan kelapa yang telah tercatat pada UD Bambang Kelapa Pasar Nusukan pada kurun waktu 2 tahun yang lampau.

\section{Soal nomor 1}

Untuk memperoleh data indikator 3terkaitsoal TRM nomor 1, maka dilakukan wawancara terlebih dahulu dengan siswa sebelum menyelesaikan TRM secara tertulis. Adapun hasil wawancara peneliti dengan MRW sebagai berikut.

P : "Apa yang ditanya dan diketahui dari soal ini ?"

S : (sambil membaca soal) "Jumlah seluruh siswa dalam kelas sebanyak 40 siswa. 6 siswa menyukai taekwondo dan karate, 4 siswa tidak menyukai keduanya, dan banyak siswa yang menyukai Karate $2 \times$ dari Taekwondo"

P : “Langkah apa yang kamu ambil untuk menyelesaikan soal ini ?"

S : "Mencari nilai siswa yang menyukai taekwondo terlebih dahulu kak. "

P : "Bagaimana caranya kamu mencari nilai siswa yang menyukai taekwondo"

S : "Kalo menurut saya, saya buat diagram venn dulu untuk mempermudah mengetahui yang diketahui serta proses merubah soal ke persamaan sehingga mudah untuk mencari nilai siswa yang menyukai taekwondo dikerjakan."

Hasil wawancara dengan siswa pada soal TRM nomor 1 sebelum mengerjakan soal secara tertulis menunjukkan bahwa siswa menjawab soal dengan menggunakan kata-kata yaitu dengan cara menyebutkan apa yang diketahui dan apa yang ditanya serta perkiraan proses penyelesaian soal. Hal tersebut sesuai dengan hasil wawancara peneliti dengan siswa setelah mengerjakan TRM berikut.

P : “Tuliskan atau ceritakan langkahlangkah penyelesaian soal ini dengan bahasamu sendiri yang mudah di pahami ?"

S : "Dalam soal ini diketahui jumlah seluruh siswa dalam kelas sebanyak 40 siswa. 6 siswa menyukai keduanya, 4 siswa tidak menyukai keduanya, dan banyak siswa yang menyukai Karate $2 \times$ Taekwondo. Yang ditanyakan banyak siswa yang menyukai Karate?

Pertama mancari banyak siswa yang menyukai taekwondo dengan cara mengubah soal kedalam model matematika yaitu

$$
\begin{aligned}
40 & =4+3 \mathrm{~T}-6 \\
40-4+6 & =3 \mathrm{~T} \\
42 & =3 \mathrm{~T} \\
\mathrm{~T} & =14
\end{aligned}
$$

Karena disoal diketahui siawa yang menyukai karate tadi $2 \times$ Taekwondo maka banyak siswa yang mneyukai karate adalah $2 \times 14=28$."

Berdasarkan wawancara dengan siswa pada Tes Representasi Matematis soal nomor 1 diperoleh informasi bahwa siswa menjawab soal dengan menggunakan kata-kata atau teks tertulis 
dengan keterangan yang tepat. Sehingga, berdasarkan hasil wawancara sebelum MRW mengerjakan TRM dan setelah MRW mengerjakan TRM soal nomor 1, maka dapat dikatakan bahwa MRW dapat menjawab soal dengan menggunakan kata-kata. Hal ini menunjukkan bahwa siswa memenuhi indikator representasi matematis yaitu kata-kata atau teks tertulis.

Hal tersebut sesuai dengan hasil penelitian Aprila (2016) yang menyatakan bahwa siswa berkemampuan tinggi dalam memecahkan masalah menggunakan representasi simbol, grafik, dan tabel.

\section{Soal nomor 2}

Untuk memperoleh data indikator 3terkaitsoal TRM nomor 2, maka dilakukan wawancara terlebih dahulu dengan MRW sebelum menyelesaikan TRM secara tertulis. Adapun hasil wawancara peneliti dengan MRW sebagai berikut.

P : "Apa yang ditanya dan diketahui dari soal ini ?"

S : (sambil membaca soal) "Diketahui harga baju dan celana Rp. 80.000 dan Rp. 100.000. Terdiri dari 3 toko Toko Rame, Toko Damai, Toko Indah masing-masing toko terdapat diskon Baju 25\%, 20\%, dan 10\%. Celana 10\%, $15 \%$, dan 25\%. Ditanya ditoko manakah Ali akan berbelanja agar diperoleh harga yang paling murah ?"

P : "Langkah apa yang kamu ambil untuk menyelesaikan soal ini ?"

S : "Mencari harga beli setelah diskon"

$\mathrm{P}$ : "Bagaimana caranya kamu mencari harga beli setelah diskon ?"

S : "Kalo menurut saya, saya kalikan harga barang sebelum diskon dengan persen diskon kemudian saya kurangi dengan harga setelah diskon"

Hasil wawancara dengan MRW pada soal TRM nomor 2 sebelum mengerjakan soal secara tertulis menunjukkan bahwa MRW menjawab soal dengan menggunakan kata-kata yaitu dengan cara menyebutkan apa yang diketahui dan apa yang ditanya serta perkiraan proses penyelesaian soal. Hal tersebut sesuai dengan hasil wawancara peneliti dengan siswa setelah mengerjakan TRM berikut.

P : “Tuliskan atau ceritakan langkahlangkah penyelesaian soal ini dengan bahasamu sendiri yang mudah dipahami ?"

S : "Jadi untuk mengetahui masingmasing harga di setiap toko setelah mendapatkan diskon yaitu dengan cara mencari harga baju dan celana setelah di diskon. Kemudian saya bandingkan masing-masing harga disetiap toko. Berdasarkan penyelesaian saya Ali akan berbelanja di toko Rame untuk memperoleh harga yang paling murah. Saya ambil contoh toko Rame ya kak ? misal toko rame kan untuk diskon baju $25 \%$ sedangkan diskon celana $10 \%$. Saya membuat tabel seperti soal kemudian mensubtitusikan setiap diskon saya ambil diskon baju $25 \%$ maka persamaan matematikannya $\frac{25}{100} \times$ Rp. $80.000=$ Rp. 20.000.

Maka harga setelah diskon adalah Rp. $80.000-$ Rp. $20.000=$ Rp. $60.000^{\prime \prime}$

Hasil wawancara dengan MRW pada soal TRM nomor 2 diperoleh informasi bahwa MRW menjawab soal dengan menggunakan kata-kata atau teks tertulis yaitu subjek menjelaskan secara runtut apa yang dimaksud dalam penyelesaianya mulai dari mencari har- 
ga setelah barang mendapat diskon, menjumlahkan hasil dari pembelian kedua barang, serta membandingkan harga beli dimasing-masing toko.

Berdasarkan hasil wawancara sebelum MRW mengerjakan TRM dan setelah mengerjakan TRM soal nomor 2, maka dapat dikatakan bahwa MRW dapat menjawab soal dengan menggunakan kata-kata. Hal ini menunjukkan bahwa siswa memenuhi indikator representasi matematis yaitu katakata atau teks tertulis.

Hal tersebut sesuai dengan hasil penelitian Sulastri (2017) yang menyatakan bahwa siswa yang berkemampuan tinggi dan rendah memenuhi indikator kemempuan representasi matematis, yaitu menyajikan data atau informasi dari suatu masalah ke representasi tabel, menyelesaikan ma-salah yang melibatkan ekpspresi matematis, serta menuliskan langkah-langkah peneyelesaian dengan kata-kata.

Hasil penelitian ini sesuai dengan hasil penelitian Saifuddin (2013) yang menyatakan bahwa siswa berkemampuan matematika tinggi membuat persamaan matematika dari represen-tasi yang diberikan, penyelesaian masalah dengan melibatkan ekspresi matematis, menggunakan representasi visual untuk menyelesaikan masalah, serta menjawab permasalahan dengan menggunakan kata-kata atau teks tertulis. Hal ini menunjukkan bahwa keberhasilan pemecahan masalah matematika tidak hanya dipengaruhi oleh pembelajaran matematika tetapi juga dipengaruhi oleh kemampuan representasi matematis siswa (Goldin, 1998)

\section{SIMPULAN}

Siswa berkemampuan matematika tinggi dalam menyelesaikan soal menggunakan representasi visual untuk menyelesaikan masalah, membuat persamaan matematis atau ekspresi matematis, serta menjawab permasalahan dengan menggunakan kata-kata atau teks tertulis dengan hasil penyelesaian soal sebagian besar benar. Apabila peneliti lain melakukan penelitian yang serupa dengan penelitian ini diharapkan mempertimbangkan dan mempersiapkan durasi waktu yang panjang untuk proses wawancara agar wawancara dapat dilakukan secara mendalam serta terperinci sehingga bisa memperoleh data yang maksimal.

\section{DAFTAR PUSTAKA}

Aprila (2016). Representasi Matematis Siswa dalam Memecahkan Masalah Matematika. Surabaya: UNESA.

Catharina. (2016). Analisis Representasi Matematis siswa SMP melalui Pendekatan Pendidikan Matematika Realistik. Yogyakarta : Universitas Sanata Dharma Yogyakarta.

Goldin, G. A. (1998). Representational Systems, Learning, and Problem Solving in Mathematics. Journal of Mathematical Behavior, 17 (2), 137-1 65.

Istadi, Kusmayadi T. A, Sujadi I. (2017). Students'Mathematical

Representations on Secondary School in Solving Trigonometric Problems. International Conference on Mathematics: Education, Theory and Application. Series 855.

NCTM. (2000). Principles and Standars for school Mathematics. Reston: VA:NCTM. 
Indonesian Journal of Mathematics and Natural Science Education, 1 (2), 2020

Fitri Ningrum Setiawati,Soffil Wadadah, Eka Nurmala Sari Agustina

Ratumanan, G.T. \& Laurens, T. (2011). Evaluasi Hasil Belajar pada Tingkat Satuan Pendidikan. Surabaya: UNESA University Press.

Rusminati, Susi H. (2014). Representasi Eksternal Siswa dalam Pemecahan Masalah Desimal ditinjau dari Kemampuan Matematika. Surabaya : UNESA.

Saifuddin. (2013). Representasi Dalam Memecahkan Masalah Matematika Ditinjau Dari Tingkat Kemampuan Matematika siswa Pada Materi Lingkaran di kelas VIII SMP. Surabaya: UNESA.
Sulastri, dkk. (2017). Kemampuan Representasi Matematis Siswa SMP Melalui Pendekatan Pendidikan Matematika Realistik. Aceh: Universitas Syiah Kuala.

Susanah. (2016). Representasi Matematis Siswa dalam Memecahkan Masalah Matematika pada materi Lingkaran. Surabaya: UNESA.

Widadah, S. (2015). Profil Konflik Kognitif Dalam Memecahkan Masalah Dengan Intevensi Ditinjau Dari Perbedaan Gender. Jurnal Edukasi, 1(2), 157-180. 